\title{
CONSULTING AS A PEDAGOGICAL GUIDANCE TECHNOLOGY IN THE CONTINUOUS EDUCATION OF A PEDAGOGUE
}

\author{
Zoya Lukashenia \\ Baranovichi State University, the Republic of Belarus \\ Natallia Sianiuta \\ Baranovichi State University, the Republic of Belarus
}

\begin{abstract}
The present day tendency of rapid constant changes of the informational and technological space surrounding a pedagogue, suggests the necessity of continuous education. The necessity of constant renovation of knowledge leads a pedagogue to obtain new competences, to the emergence of new educational practices. As a result of high competition in all spheres of society the client-orientated course of modern system of professional education makes a pedagogue search for new forms of getting competences, which are not set in the frames of certain disciplines and thus provide the continuity of educational processes. Here we suggest consulting, having been worked out as a pedagogical technology that guaranties the achievement of the set goals, reproduction and replication. The purpose of our research is to substantiate the expediency of using the pedagogical technology of consulting to support the process of continuous professional training of a teacher directly at the workplace. The article deals with the theoretical stage results of our research in working out a consulting model as a pedagogical technology of continuous pedagogue's educational guidance as well as the analysis of pedagogue-participants' opinions concerning the pilot approbation of this model.
\end{abstract}

Keywords: continuous education, consulting, consulting guidance, pedagogical technology.

\section{Introduction}

The rapid development of science, modern industrial technologies and open for innovation communication education make it all possible to develop a personality of any specialist and his professional growth, but at the same time they require a high level of requirements to his competences. A modern specialist should be ready to work in the high conditions of uncertainty: to make decisions quickly, to react to the changes in any working conditions, to distribute and to redistribute the resources and to control the time in the stream of work tasks. 
Thus, there is a need for fast education, the aim of which is that professional training of a specialist to the narrow realm of tasks for that working place at the present moment. Innovation changes in all spheres of the society suggest the constant changes in the complex of specialized tasks that will consequently lead to provide a constant personnel development according to them. The modern generation realizes the need for life-long learning (Bazarova, Waganova, Dagbaeva, Namsaraev, \&Fomizkaya, 2018; Cranton, 2016; Sun \& Kang, 2019).

The educational sphere in this tendency is not an exception. They actualize the requirements to pedagogue's forming competences to project the educational process that are characterized by active subjective position of the learners to study, free in time and space. The position of a pedagogue is that of a consulter, guiding the process of search and selection actual for learning situation information for teaching the subjects of training, those means and methods to work with such information, to assist promoting the achievement of their goals in education.

Our theoretical research results (Macfarlane \& Burg, 2017; Macheridis \& Paulsson, 2019; OECD, 2019) allow stating the appropriateness of consulting guidance to solve these tasks (Lukashenia, 2016, p.136-137). In the frame of our research, the activity on consulting guidance is technologized and is positioned as a pedagogical technology that is realized in the continuous mode.

Different aspects of continuous education have been studied in the works of many Belarusian (V.A. Gaisenok, N.I. Zaprudsky, T.A. Lopatik, A.P. Monastyrny, S.N. Nevdakh, N.V. Susha, K.A. Petrov, V.G. Reut and others), Russian (I.V. Bestuzhev-Lada, A.A. Verbitsky, S.G. Vershlovsky, B.S. Gershunsky, G.P. Zinchenko, O.V. Kuptsov, F.I. Peregudov, V.N. Turchenko, F.G. Filippov and others) and foreign (A. Groplei, R. Dive, K. Knepper, P. Lengran, Zh. Malglev, A. Pen and others) scholars. However, according to our point of view, the questions of practical realization of theoretical results to the problem of pedagogue's continuous education as a technological consulting process have been studied insufficiently.

The purpose of our research is to substantiate the expediency of using the pedagogical technology of consulting to support the process of continuous professional training of a teacher directly at the workplace.

\section{Literature review}

As mentioned above, the need for continuous cultural and professional education in the modern world is a universally accepted tendency [Berlin Communique: Realising the European Higher Education Area, 2003; Bologna Declaration, 1999]. The nature of continuous educational processes is orientated 
to fulfil those social functions that are realized on the basis of meaningful values. These values find their reflection in the accepted at every historical stage those paradigm bases, domineering in different periods of the human society development. They define the choice of the matter, forms, methods and means of teaching, the position of pedagogues and learners, a way of life of educational establishments and so on.

The consulting model as a pedagogical guidance technology of a pedagogue's continuous education is based on the methodology bases, shown in the unity of the following approaches:

- $\quad$ a system-synergetic-integrated general sciences level approach;

- a certain-scientific level (psycho-pedagogical sciences) represents andragogical and praxeological approaches;

- competence and context approaches show the peculiarities of realization of consulting guidance in the continuous education of a pedagogue at the methodological level.

The theoretical grounds of consulting model development as a pedagogical guidance technology in the continuous education of a pedagogue include the leading theses of the following theories and concepts:

- the ideas of humanistic psychology A. Maslow and "a fully functioning man" of K. Rodgers;

- the key theses of psycho-didactic (I.S. Yakimanskaya) and culturological (E.V. Bondarevskaya) concepts of personalityorientated education and upbringing (V.V. Sericov);

- $\quad$ the ideas of personality freedom pedagogics concept in the process of education (J.S. Gasman, P.Ya. Layudis); self-organized pedagogical activities concepts (S.V. Kulnevich); personality professional development concepts (L.M. Mitina);

- management theory leading theses (V.G. Afanasiev, A.I. Berg, M.M. Potashnik, P.I. Tretiakov, T.I. Shamova and others).

In the technological process of consulting guidance of a pedagogue's continuous education we followed the key ideas in the research of pedagogical technologies problems, laid out in the works of E.P. Argunov, V.P. Bespalko, V.I. Bogolyubov, I.V. Borisova, A.M. Voronin, V.V. Guzeev, A.E. Denisov, O.V. Dolzhenko, T.A. Ilyina, M.V. Klarin, G.V. Latyshev, T.A. Mosharova, E.I. Mashbits, G.I. Mikhailovskaya, V.M. Monahov, V.Yu. Pityukov, G.K. Selevko, V.V. Sericov, V.D. Simonenko, N.F. Talyzina, V.A. Slastenin, O.K. Filatov, A.I. Yakovlev and others.

In working out the consulting guidance of a pedagogue's continuous education model, we were guided by the research in the realm of reflection methodology (O.S. Anisimov, O. Genisaretsky, Yu.L. Kotlyarevsky, 
V.A. Lefebvre, V.M. Rozin, B.V. Sazonov, A.A. Tyukov, A.S. Shantser, G.P. Shchedrovitsky and others), that are the theory in organizing and realization of consulting activities with the use of experimental method of gametechnical modelling (game-modelling).

Educational process game forms turn out to be the most effective means to stimulate team activities and creativity, to overcome participants' thinking patterns. The game achievements are admitted as educational results (Lefebvre, 2010, p.11).

Consulting in our research is regarded as a process of consulting function realization of the educational establishment that suggests the grounds for the management decisions which is provided by the working out and realization of the concrete practical recommendations on the problems of management in joint activity of consulters and clients (Lukashenia, 2016, p. 7).

\section{Methodology}

The functioning of modern educational establishments of any profile in accordance with the present tendency of educational humanization processes is oriented to the subjects of educational practice as the main value. Due to this, we regard educational establishment pedagogues and specialists who are having some difficulties in their professional practice realization where they introduce their own initiated novelties. Consulting in the frame of our research means the transition of the client into the position of a researcher where he fulfils his own innovation activity and life style.

A consulter in our research is a collective subject that is formed for every concrete problem of some concrete client of the staff who has already passed a special game-technical training and voluntary implement the work of the educational establishment consulting service (Lukashenia, 2016, p.241).

This service is to provide by the teaching staff itself of the organization “educational establishment” its specialists' professional competences qualitative changes that provide productive functioning of this organization subsystem. According to our supposition, due to the effect of synergy the functioning in the productive innovation activity mode of the subsystems will lead to the same mode of functioning of its wholeness (Lukashenia, 2016, p.180). The consulting guidance of a pedagogue's professional practice represents a form of his continuous education realization that suggests the working activities integration of a pedagogue with the process of his teaching directly at the working place.

To provide the productivity of communication interaction of the consulting guidance participants in the continuous education of a pedagogue a special graphic language is introduced - the language of schemes and schematic drawings that we borrowed from game-modelling methodology 
(Anisimov, 2018). Communication model of the scheme language origin belongs to V.A. Lefebvre (Lefebvre, 2010).

Consulter's position presupposes some constant 'pushing up' of the participants from one stage of communication to another, help in the moments of some difficulties concerning the necessity to draw a train of thought scheme. The schematization techniques are learned by the consulting participants in the game-modelling process in their individual rate of mode.

While realizing consulting activities we use consultation technologies and techniques based on the concept of reflective-creative psychology and pedagogics, realized through intensive-game methods, providing innovation activities in education. Here we mean tutoring, supervision, moderation, coaching, facilitation etc.

Tutor activities in the set of consulting means are used if needed to support the individual process of the consulting project implementation introducing some changes in the practice realized by the client. Supervision takes place in teaching specialists of the educational establishment "consulting service" personnel resources. The mobilization tasks of consulting participants to make decisions quickly are successfully solved with the help of moderation technology. We see the explanation to this due to the time resources limits: process-teaching consulting usually takes to days off. Difficult problems consultation is done by means of consulting event holding integrating several consulting activities. Coaching is rarely used: with an opportunity to bring qualified specialists in this field (outer service).

While realizing consulting as a pedagogical guidance technology of a pedagogue's continuous education we understand that every specialist of an educational establishment is the carrier of unique personal significance and professional activities experience. Consequently, this supposes invariance of the worked out in the process of consulting activities aims, actual for the development of both - the educational establishment and every pedagogue. Thus, there is a necessity in their coordination. In the process of consulting guidance of a pedagogue continuous education this problem is solved by the use of SWOT-analysis and ways of forecasting; "top-down forecasting approach" and "bottom-up forecasting approach" online up to the consensus of all consulting participants. Correspondingly, primordially in on-line mode a unique for the whole educational establishment a matrix of participants' values is created that is consecutively corrected in accordance with outer calls and inner needs of the consulted.

The combination of group and individual forms of consulter-client interaction in fulfilling distance forms of consulting guidance is realized through the use of synchronous (webinar, electronic conference, Skype etc.) and 
asynchronous (e-mail, LMS Moodle, electronic conference etc.) means of communication.

The adult education technology assumes the maximum of individualization, the record of their professional experience, intellectual and cultural potential. Consulting guidance is one of the effective educational forms realizing humanistic principles of modern education and its personality orientation. Consulting guidance stimulates the conscious-content reflection of the participants, assisting the adoption of professional activities cultural norms by the individual.

The real professional practice situations, taken from the experience of the consulting participants are the objects of the reflection analysis in the process of consulting activities. Thereby we mainly imply a process-teaching consulting type, problem situations of professional practice may develop spontaneously or they may be created purposefully by means of the corresponding components of continuous education. The result of their solution is the development of new professional experience by the participants of the consulting activities.

That new professional experience of the participants, ingenuously achieved and understanding its innovation take place spontaneously at the beginning of the game experience and mainly by intuition. Game modelling increases the possibility of reflection realization of the innovation in the obtaining professional experience and intensifies the process of its accumulation. Reflection processes and mechanisms realize, along with normative and critical, a research function, which provides continuity in the professional training of a pedagogue.

The simulation experiments allow us to evaluate the productivity of the worked out control decision that radically lowers the risk of losses from groundless decisions in real practice. The structural schematization of the functioning processes in the consulted organization along with their gamemodelling in help the consulting guidance participants achieve the best understanding of the problem situation and forecast the made choice consequences.

In game modelling, we create model types of executive actions that are used in the analysed problem situations. Their content makes a consulting client give up a usual way of the executive function realization. The content mobility in game modelling (scripts and plots) is a favourable basis and condition to intensify the event participants' development through the processes of selfcorrection. 
SOCIETY. INTEGRATION. EDUCATION

Proceedings of the International Scientific Conference. Volume V, May $22^{\text {th }}-23^{\text {th }}, 2020.190-199$

\section{Results and Discussion}

The given above them technology model of consulting guidance in the continuous education of a pedagogue had its approbation in three higher educational establishments of the Republic of Belarus (720 participants), in three Russian higher educational establishments (379 participants), in advanced training of Belarusian (165 participants) and Bulgarian (97 participants) schoolteachers.

The consulting activities were held in the frame of the guidance in the implementation process of those novelties initiated by the universities pedagogues and schoolteachers themselves in their own professional practice. The novelties had the local character and meant the changes in the taught disciplines content or in the methods of its learning organization. The guidance was brought into effect by means of process-teaching consulting's, webinars and individual on-line consultations.

The realized achievement of the set goals of the held consulting activities in all educational establishments, a reproduction and replication possibility of the technological algorithm (certified by the taken "geography") allow qualifying consulting guidance in the continuous education of a pedagogue as a pedagogical technology.

In the process of consulting activities, we carried out an anonymous questionnaire where there were 1130 respondents from 1361 participating in the consulting activities of pedagogues.

One of the tasks in the carried out questionnaire was to reveal that positive motivation of the pedagogues to continuous education in the form of consulting.

According to the results of the questionnaire 97,3\% (1099 p.) of the respondents mentioned that they had made a decision about constant participation in process-teaching consulting on the guidance of their own professional practice; 1026 pedagogues (90,8\% of the total) consider consulting as a pedagogical guidance technology in the continuous education of a pedagogue, an efficient form of their own professional training realization in the continuous mode. To ground this fact they gave the following arguments:

- in the process of consulting guidance a pedagogue's motivation to introduce innovation changes in their own professional practice is stimulated (marked $89,1 \%$ of all questioned or 1007 p.);

- the participants' competence level in the sphere of professional pedagogical activities is rising (marked 1059 p. or $93,7 \%$ of all questioned) and in the innovation sphere (marked 1094 p. or $96,8 \%$ of all questioned);

- the skills in working out a project on introducing the innovation changes in their own professional practice (marked 1059 p. or $93,7 \%$ 
of all questioned) and the project's implementation programs (marked 1028 p. or $90,9 \%$ of all questioned).

In the statistical data manipulation, we used a two-factor variance analysis, in which, as a variable was the self-appraisal data of the consulting participants and experts' assessment. Calculated for Fisher criterion the statistical significance level $(p=0,000013)$ turned out to be considerably smaller than admissible $(0,05)$ that indicates the statistical significance of the finding.

Thus, the consulting guidance in the continuous education of a pedagogue contributes to the grows of self-determination abilities and general creativity of its participants through concrete potential of the definite type of activities. In the process of consulting activities realization, optimal conditions and suppositions to innovation-creative and akmeological self-realization of its participants are created. The agility of requirements to game conduct demands a subjective selforganization and mobility. It becomes a precondition to pedagogue's new decisions and high results through the motivation-self-determination process.

The present research stage results on the problem of consulting guidance in the continuous education of a pedagogue time and again were discussed at scientific and science-practical conferences in the Republic of Belarus, Bulgaria, Poland, the Russian Federation.

\section{Conclusions}

An important result of consulting as a pedagogical technology of continuous education guidance of a pedagogue in the process of game modelling is the creation of a project and program of clients' organization functioning in the changed to some innovation situation conditions. The use of the worked in methodology structural schemes makes it possible to reveal the differences in the index providing the consulted professional practice of a pedagogue functioning in "as is" mode from the planned data "as it must be". The research of the professional future let us add and widen the scientific concept of the professional formation, development and self-determination of consulting guidance participants.

Thus, consulting guidance as a form of a pedagogue continuous professional education directly at the work place will be effective and practically feasible under the condition:

- that being realized in its answer to the real demands of the professional practice it will take account of the world tendencies in the world educational systems innovation development and it will be based on their conceptual grounds; 
- $\quad$ under the condition of reasonable combination in the universality of the requirements to the pedagogical profile specialist in the world community with its national identification;

- $\quad$ if in the process of its realization the decisions on innovation changes in the professional practice of a definite pedagogue will obligatory be coordinated with the strategy development (innovation included) of the educational establishment;

- if the arsenal of consulting guidance means used during its realization includes progressive consulting techniques and technologies, information technologies, modern means of communication interaction;

- if in the structure of the educational establishment there is a "consulting service" subdivision the consulters of which upgrade their special qualification in the continuous supervision mode, involving outer service as well (coaching).

They lay emphasis on the practical problems of a pedagogue in the process of consulting realization as a technological form of the pedagogical staff continuous professional training at the work place directly. This position let us react efficiently to any of his educational demands, offering the content and methods of training that will maximum take into consideration those working conditions of a pedagogue and those real difficulties he comes across in his professional activities. Herewith the visible positive changes form in a pedagogue additional inner motivation to learning and upgrading of his professional competence in the continuous mode.

The practical approbation results, represented in this consulting model research that we used for a pedagogue's continuous education guidance directly at his work place, confirm its productivity in the set goals achievements well as the pedagogical technology correspondence according to reproduction and replication characteristics.

\section{References}

Anisimov, O. (2018). Skhemy i yazyk skhematicheskikh izobrazheniy. Moskva: FGOU RosAKO APK.

Bazarova, T., Waganova, W., Dagbaeva, N., Namsaraev, S., \& Fomizkaya, G. (2018). A system of continuing pedagogical education in Russia: current state and prospects. International Journal of Educational Management, 32(7), 1215-1222. Retrieved from https://doi.org/10.1108/IJEM-11-2017-0326

Berlin Communique: Realising the European Higher Education Area. (2003). Retrieved from https://enqa.eu/wp-content/uploads/2013/03/BerlinCommunique1.pdf 
Bologna Declaration. (1999). Joint Declaration of the European Ministers of Education. Retrieved from http://www.magna-charta.org/resources/files/BOLOGNA_DECLARA TION.pdf

Cranton, P. (2016). Continuing Professional Education for Teachers and University and College Faculty. Contexts, Practices and Challenges: Critical Insights from Continuing Professional Education, 151, 43-52.

Lefebvre, V. (2010). Lectures on the Reflexive Games Theory Paperback. Los Angeles: Leaf \& Oaks Publishers.

Lukashenia, Z. (2016). Konsalting v vysshemuchebnomzavedenii: monografiya. Baranovichi: Baranovichskiy gosudarstvennyy universitet.

Macfarlane, B., \& Burg, D. (2017). Legitimation, Professionalisation and Accountability in Higher Education Studies: An Intergenerational Story. Studies in Higher Education, 42(12), 459-469. Retrieved from https://doi.org/10.1080/03075079.2017.1376640

Macheridis, N., \&Paulsson, A. (2019). Professionalism between profession and governance: how university teachers' professionalism shapes coordination. Studies in Higher Education, 44, 470-485. Retrieved from https://doi.org/10.1080/03075079. 2017.1378633

OECD. (2019). Trends Shaping Education 2019, OECD Publishing, Paris. Retrieved from https://doi.org/10.1787/trends_edu-2019-en

Sun, Q., \& Kang, H. (2019). The New Vistas of Adult and Continuing Education for Change in Asian Context: Themes and Implications. The Changing Vista of Adult and Lifelong Education in Asian Contexts: Theories and Practices from the East, 162, 139-152. 